\title{
PENGARUH PENGGUNAAN BEBERAPA JENIS FILLER TERHADAP SIFAT FISIK CHICKEN NUGGET AYAM PETELUR AFKIR
}

\author{
Sylvia Komansilan
}

\author{
Fakultas Peternakan Universitas Sam Ratulangi Manado. 95115
}

\begin{abstract}
ABSTRAK
Penelitian mengenai pengaruh penggunaan beberapa jenis filler terhadap sifat fisik chicken Nugget telah dilakukan. Penelitian ini bertujuan untuk mengetahui dan mempelajari jenis filler yang berbeda dalam menghasilkan formulasi chicken nugget yang diterima oleh konsumen ditinjau dari sifat fisik. Penelitian ini dilaksanakan di Laboratorium Teknologi Hasil Ternak, di Laboratorium Akademi Gizi Manado, dan Laboratorium Pertanian Universitas Sam Ratulangi Manado. Bahan penelitian ini adalah daging dan lemak ayam petelur afkir sebanyak 6400 gram yang dibagi menjadi 16 sampel dengan berat masing-masing 100 gram lemak dan daging 300 gram. Penelitian ini dilaksanakan melalui suatu percobaan dengan menggunakan Rancangan Acak Lengkap (RAL) dengan 4 ulangan .Sebagai perlakuan digunakan beberapa jenis filler yaitu; T1 (tepung Sagu), T2 (tepung tapioka), T3 (tepung maisena), T4 (tepung beras ketan). Parameter mutu chicken nugget( daya mengikat air, keempukan dan susut masak) . Dari hasil penelitian ini menunjukkan bahwa bahan pengisi filler dengan menggunakan tepung tapioca (T2) dan tepung sagu (T1) menghasilkan chicken nugget yang lebih baik dibandingkan dengan tepung maisena (T3), tepung beras ketan (T4).
\end{abstract}

Kata Kunci: Pengaruh, Filler, Chicken Nugget, Laboratorium

\begin{abstract}
THE INFLUENCE OF THE USE OF VARIOUS FILLERS TOWARDS THE PHYSICAL CHARACTERISTICS OFCHICKEN NUGGET. The objectives in this research is to observe and study the fillers that vary in producing the formulation of chicken nugget which were received by the consumers observed from the physical. This research was conducted at the Laboratory of Animal Science Sam Ratulangi University Manado, The Laboratory of Nutrient College Manado and The Laboratory of Agliculture Sam Ratulangi University Manado. The material used in this research was meat and fat of non-productive layer (culled) as much as 6400 gram, devided into 16 samples, each sample weighed 100 gram fat and 300 gram meat. The research was carried out through an experient, a completely randomized design with four replications. The fillers Used in this treatment are; T1 (Sago), T2 (Tapioka) T3 (Maizena), T4 (Glutten Rice). The Quality of chicken nugget according to the parameter ini this research was as follows; the phsycal characteristic (Water Holding Capasity, Tenderness and cooking loss). From the result of this research it was concluded that the filler which used tapioca (T2) and Sago (T1), had produced chicken nugget which was much better, compared to the use of maizena (T3), glutten rice flour (T4), and generally accepted by the consumers, supported by their characteristics.
\end{abstract}

Keyword: Influence, Filler, Chicken Nugget, Laboratory 


\section{PENDAHULUAN}

Produk peternakan yang cukup besar permintaannya menunjukkan kebutuhan yang cenderung meningkat setiap tahunnya berupa daging. Daging mempunyai manfaat besar bagi manusia, karena merupakan makanan yang bergizi tinggi yaitu kaya akan protein, mineral, vitamin dan lemak serta zat-zat lain yang kesemuanya sangat dibutuhkan tubuh.

Disamping potensi produksi dan pasar yang tersedia, produk peternakan juga mempunyai potensi teknologi yang bisa diterapkan untuk meningkatkan nilai tambah produksi peternakan yang ada.Teknologi tersebut meliputi teknologi pananganan yang ditekankan untuk mengurangi atau menekan terjadinya kerusakan atau kehilangan produksi peternakan serta teknologi pengolahan.Pada prinsipnya bahan pangan mentah dapat dijadikan produk makanan siap dikonsumsi.Pesatnya perkembangan produk pangan seperti ini tidak lepas dari perkembangan ilmu pengetahuan tentang sifat fungsional komponen-komponen pangan yang terlihat jika komponenkomponen ini sudah berinteraksi dengan komponen-komponen lainnya dalam suatu sistim makanan dengan multi komponen.

Daging ayam petelur afkir yang sudah tua atau yang kurang produkstif mempunyai sifat lebih alot dibandingkan dengan daging ayam broiler. Upaya-upaya telah dilakukan agar daging ayam petelur afkir lebih empuk serta bertujuan untuk penganekaragaman produk hasil ternak lainnya antara lain: dendeng, abon bakso, dan lain sebaginya. Salah satu potensi yang cukup besar yakni tersedianya ayam afkir dari ayam petelur yang memiliki kualitas yang lebih rendah.Oleh karena itu diperlukan teknik pengolahan sebagai upaya peningkatan daya guna ayam petelur afkir sehingga lebih disukai oleh konsumen yang semkin menuntut variasi produk olahan dengan demikian disversifikasi dari produk ini semakin penting, dan perlu dilakukan pengembangan indnustri pengolahan hasilhasil peternakan.

Pengolahan daging seperti halnya pengolahan bahan lainnya bertujuan untuk memperpanang masa simpan, memperbaiki sifat organoleptik, menambah variasi bentuk olahan daging, memungkinkan tersedianya produk daging siap saji.Pengolahan daging di Indonesia sudah banyak dilakukan, baik yang diolah secara sederhana maupun dengan alat-alat modern.

Chicken nugget adalah suatu bentuk produk olahan daging ayam yang digiling, dicetak dengan menggunakan cetakan diberi bahan pelapis dengan atau tanpa penambahan bahan makanan lain dan 
bahan tambahan makanan yang diizinkan. Dalam proses pembuatan chicken nugget selain bahan cacahan daging dan bumbu sering ditambahkan bahan pengisi filler. Maksud penambahan bahan pengisi pada produk daging emulsi adalah untuk: meningkatkan stabilitas emulsi, meningkatkan daya ikat air produk daging, meningkatkan flavor, mengurangi pengerutan selama pemasakan, meningkatkan karakteristik irisan prouduk dan mengurangi biaya formulasi. Tepung berpati yang biasa digunakan dalam pembuatan chicken nugget adalah tepung tapioca. Beberapa jenis tepung berpati yang berpotensi sebagai filler adalah tepung sagu, tepung maizena dan tepung beras ketan. Tepung sagu mempunyai kelebihan yaitu ukuran granula yang lebih besar serta kandungan amilosa yang tinggi, tepung maizena merupakan pati yang di ekstrak dari jagung, dan mengandung kadar amilopektin yang cukup tinggi, serta tepung beras ketan yang juga mengandung kadar amiolopektin yang tinggi. Adanya amilosa dan amilopektin dalam pati bahan pengisi menyebabkan kecenderungan menyerap air serta sifat gelatinisasi yang baik. Sifat ini ditandai oleh tidak larutnya granula pati dalam air dingin namun dapat mengembang dalam air hangat.Pilihan untuk memanfaatkan tepung berpati tersebut selain untuk meperluas kegunaannya juga tersedia dipasaran. Bahan-bahan berpati ini banyak terdapat di daerah Sulawesi Utara dan merupakan potensi yang sangat besar untuk memberdayakan produk-produk lokal yang ada tanpa pasokan dari daerah lain. Demikian selanjutnya dengan memnfaatkan tepung-tepung berpati sebagai filler akan dapat dihasilkan aneka rasa nugget.

Penelitian ini diarahkan untuk mempelajari bahan pengisi filler yang mempunyai struktur, sifat fungsional dan kadar protein, lemak abu serta karbohidrat yang beragam sehingga hal ini akan mempengaruhi sifat fisik, darichicken nugget yang dihasilkan. Untuk itu perlu dikaji pengaruh penggunaaan beberapa jenis filler, terhadap sifat fisikchicken nugget.

\section{MATERI DAN METODE PENELITIAN}

\section{Tempat dan Waktu Penelitian.}

Penelitian ini dilaksanakan di Laboratorium Teknologi Hasil Ternak Fakultas Peternakan, di laboratorium Akademi Gizi Manado, dan Laboratorium Fakultas Pertanian Universitas Sam Ratulangi Manado. 


\section{Materi penelitian.}

Bahan-bahan untuk pembuatan chicken nugget terdiri dari daging dan lemak dari ayam petelur afkir strain Logman sekitar 24 bulan. Sebagai bahan pengisi digunakan tepung tapioca, tepung sagu, tepung maizena dan tepung beras ketan. Bumbu-bumbu (merica bubk, penyedap, bawang putih) selain bumbu digunakan tepung panir, telur, susu bubuk serta es. Alat-alat yang digunakan yaitu, pisau, telenan food procecor, blender, plastic, dandang kukus, kompor,timbangan analitik, cetakan kue, untuk anlisa kimia digunakan cawan porselen, labu kjedal, oven, gelas ukur, botol timbang, desikator, waterbath (penangas air) alat yang digunakan untuk anlisa sifat fisik nugget yaitu; Penetrometer, planimeter, alat beban tekan seberat $35 \mathrm{~kg}$ untu mengukur daya mengikat air, kertas saring, Whatman no 41, stopwatch.

\section{Metode Penelitian.}

Penelitian ini menggunakan Rancangan Acak Lengkap (RAL) yang terdiri dari 4 perlakuan dan 4 ulangan . Sebagai perlakuan adalah Chicken Nugget dengan beberapa jenis filler yaitu:

$\mathrm{T} 1=$ menggunakan tepung sagu

$\mathrm{T} 2$ = menggunakan tepung tapioka

$\mathrm{T} 3$ = menggunakan tepung maizena $\mathrm{T} 4=$ menggunakan tepung beras ketan

\section{Analisis data.}

Data yang diperoleh dari masingmasing parameter yang diukur diolah dengan menggunakan minitab.Data tersebut dianalisis dengan analisis keragaman (analiysis of variance). Untuk mengetahui perlakuan-perlakuan mana yang berbeda nyata secara statistic dilakukan pengujian dengan uji Wilayah bergandan Duncan (Duncan multiple Range test).

\section{Prosedur Kerja.}

Pembuatan chicken nugget dimulai dengan menyiapkan daging ayam petelur afkir yang segar strain Logman berumur 24 bulan. Daging ayam yang telah dibersihkan dipotong-potong kemudian dicampur dengan bumbu-bumbu yang telah disediakan tambahkan bahan-bahan seperti tepung untuk setiap perlakuan masing-masing $25 \%$ tepung sagu, tepung tapioca, tepung maizena dan tepung beras ketan, penyedap $3,75 \%$ es $20 \%$, bawang putih $3,75 \%$ serta susu bubuk $3,75 \%$ dan kuning telur $10 \%$ kemudian di giling dengan food procecor. Adonan yang telah terbentuk dikukus dengan menggunakan waterbath dengan suhu yang telah ditentukan yaitu $75^{\circ} \mathrm{C}$ selama 45 menit kemudian angkat dan dinginkan dicetak dengan menggunakan cetakan masukan 


\section{Gambar 1. Prosedur pembuatan chicken nugget}

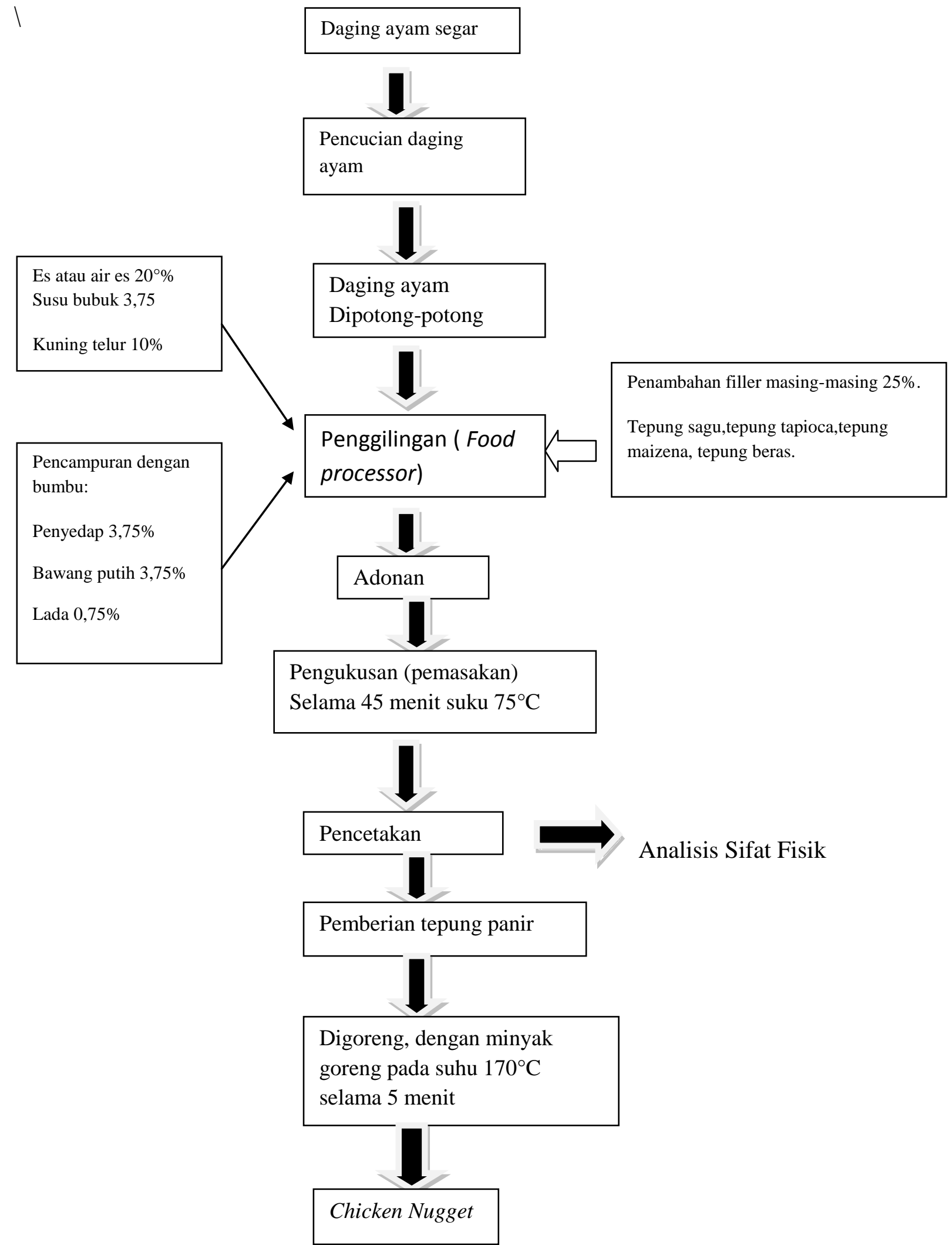


dalam kocokan putih telur, diguling dalam tepung panir dan kemudian digoreng dengan menggunakan minyak goreng pada suhu $170^{\circ} \mathrm{C}$ selama 5 menit.Dilanjutkan dengan analisis laboratorium. Untuk lebih jelasnya prosedur pembuatan chicken nugget dapat dilihat pada gambar

\section{Pengukuran Parameter Chicken Nugget}

Parameter yang dipakai selama penelitian ini terdiri dari sifat fisik, yaitu;

\section{Analisis Sifat Fisik Chicken Nugget}

a. Daya Mengikat Air. Pengukuran daya mengikat air ditentukan dengan menggunakan metode pengepresan dari Hamm (1972) yang dikemukakan oleh Swatland (1984) yaitu dengan menggunakan alat Carver press. Sampel Chicken nugget kurang lebih 0,3 gram diletakkan dikertas saring, kemudian dijepit diantara 2 kaca dan ditekan dengan beban $35 \mathrm{~kg}$ setiap $\mathrm{cm} 2$ selama 5 menit. Luas area basah (wetted area) adalah luas air yang diserap kertas saring akibat penjepitan, yaitu selisih luas lingkaran dilakukan dengan planimeter merk Hruden. Kertas saring yang digunakan adalah Whatman -1 No 41. Bobot air bebas (air daging yang terlepas karena proses penekanan) dapat dihitung dengan rumus sebagai berikut:
$\mathrm{Mg} \mathrm{H}_{2} \mathrm{O}=\frac{\text { Luas area basa } h}{0,0948}-8,0$

$\%$ air bebas $=\frac{\mathrm{Mg} \mathrm{H} 20}{300 \mathrm{mg}} \times 100$

Dengan mengetahui kadar air total daging (hasil analisis proksimat) maka kadar air terikat atau WHC dapat ditentukan

WHC = kadar air total $(\%)-$ kadar air bebas $(\%)$

b. Susut Masak. Pengukuran susut masak dilakukan dengan metode Houton, dkk (1976) dalam Soeparno (1994). Disiapkan sampel adonan chicken nugget sebanyak 10 gram untuk masing-masing perlakuan ditimbang (x) kemudian dilakukan pemasakan pada suhu $75^{\circ} \mathrm{C}$ selama 45 menit. Cairan daging yang ada dipisahkan dan sampel daging dikeringkan dengan kertas peresap agar air yang menempel pada permukaan daging meresap, kemudian dilakukan penimbangan sampel (y). Selisih berat sampel sebelum dan sesudah pemasakan disebut sebagai susut masak yang dinyatakan dalam persen. 
Perhitungan susut masak dilakukan dengan menggunakan rumus:

Susut masak $(\%)=\frac{x-y}{x} \times 100$

$\mathrm{X}=$ berat sampel sebelum dimasak

$\mathrm{y}=$ berat sampel sesudah dimasak

c. Pengukuran Keempukan Chicken Nugget (Muctadi dan Sugiyono, 1992) Pengukuran ini dilakukan dengan menggunakan alat penetrometer.Sampel dipotong dengan ukuran $2.5 \times 2.5 \mathrm{~cm}$ diletakkan pada alat penetrometer.Jarum diatur sedemikian rupa sehingga tepat menyentuh permukaan daging.Jarum skala menunjuk angka nol dan posisi pengatur jarum menyentuh pangkal jarum.Pada pangkal jarum dipasang beban 50 gram.Selanjutnya kunci jarum penetrometer ditekan dan stopwatch dihidupkan selama 20 detik.Kunci jarumdilepaskan dan pengatur jarum skala ditekan perlahan sampai menyentuh jarum. Angka yang ditunjukkan jarum skala dicatat dan keempukkan daging dinyatakan dalam $\mathrm{mm} / 20$ detik/50 gr.

\section{HASIL DAN PEMBAHASAN}

Sifat Fisik chicken nugget yang diamati dalam penelitian ini adalah: Daya Mengikat Air, Susut Masak, dan Keempukan Chicken Nuggetri Empat Macam Chicken Nugget

\section{Daya Mengikat Air.}

Daya mengikat air adalah kemampuan protein daging untuk mengikat airnya atau air yang ditambahkan selama ada pengaruh kekuatan dari luar. Daya mengikat air (DMA) dari 4 macam chicken nugget dalam penelitian ini menunjukkan bahwa daya mengikat air dari 4 macam chicken nugget berada pada kisaran 50,99\%-53,17\% sedangkan hasil penelitian dari Rompis (1988) untuk daging olahan sosis adalah 50,92-56,72\%.

Tabel 1. Sifat Fisik Dari Empat Macam Chicken Nugget

\begin{tabular}{lcccc}
\hline \multirow{2}{*}{ Parameter } & T1 & T2 & T3 & T4 \\
\cline { 2 - 5 } & Sagu & Tapioka & Maizena & Beras ketan \\
\hline Daya mengikat air $(\%)$ & $52,10^{\mathrm{a}}$ & $52,17^{\mathrm{a}}$ & $50,99^{\mathrm{a}}$ & $51,62^{\mathrm{a}}$ \\
\hline Susut Masak $(\%)$ & $1,53^{\mathrm{a}}$ & $1,60^{\mathrm{a}}$ & $1,51^{\mathrm{a}}$ & $1,50^{\mathrm{a}}$ \\
\hline Keempukan $(\mathrm{mm} / 20 \mathrm{dtk} / 50 \mathrm{gr})$ & $0,97^{\mathrm{b}}$ & $1.02^{\mathrm{a}}$ & $1,01^{\mathrm{a}}$ & $0,99^{\mathrm{ab}}$ \\
\hline
\end{tabular}


Hasil dari Indramorno (1987) melaporkan bahwa untuk daging olahan bakso mempunyai daya mengikat air 46,64$63,93 \%$. Berarti air dari hasil penelitian ini masih dalam kisaran batas daya mengikat air yang normal. Hal ini dapat dikatakan bahwa bahan pengisi (filler) pada penelitian ini dapat meningkatkan daya mengikat air. Pemilihan bahan pengisi yang digunakan berdasarkan daya serap air yang baik, walaupun tidak menunjukkan pengaruh yang berbeda antara perlakuan.

Berdasarkan hasil analisis keragaman menunjukkan bahwa daya mengikat air dari 4 macam chicken nugget memberikan pengaruh yang tidak berbeda nyata $(\mathrm{P}>0,05)$ Lama pemasakan yang sama 45 menit yang dilakukan pada saat pengukusan chicken nugget dan suhu yang sama $75^{\circ} \mathrm{C}$ pada masing-masing perlakuan yang menggunakan tepung tapioka dan tepung sagu karena kedua jenis tepung tersebut memiliki viskositas yang tinggi, dimana viskositas yang tinggi menunjukkan kemampuan pati untuk mengikat air yang sebelumnya berada di luar granula dan bebas bergerak sebelum dipanaskan kini sudah berada di luar granula dan bebas bergerak sebelum di panaskan kini sudah berada dalam butirbutir pati dan tidak dapat bergerak dengan bebas lagi. Menurut Asyiek ( 1992), tingginya daya mengikat air pada produk yang mengandung tepung tapioca dan tepung sagu karena ukuran granula dan kandungan amilosa yang sangat tinggi karena banyak mengandung gugus hidroksil dalam molekul pati sehingga menungkinkan air terikat lebih banyak. Menurut Hamm (1974) faktor-faktor yang mempengaruhi daya mengikat air adalah susunan protein myofibril yaitu aktin dan myiosin. Dengan mengurangi gaya kohesi antara molekul-molekul yang berdekatan maka jaringan akan membesar sehingga air akan terserap dan terjebak di dalam jaringan otot. Air yang terjebak dalam jaringan otot adalah air termobilisasi.Air yang terjebak dalam jaringan otot adalah terimobilisasi. Air yang terimobilisasi merupakan air yang termobilisasi merupakan air yang berada pada lapisan tengah antara air bebas dan air terikat serta berada pada daerah molekul yang mempunyai muatan (Forrest et al., 1975). Daya mengikat air oleh protein daging dipengaruhi oleh beberapa faktor yaitu $\mathrm{pH}$, pelayuan, pemasakan atau pemanasan (Lawrie 1979 dan Soeparno 1994).Ockerman (1983) mengatakan bahwa daya mengikat air dipengaruhi oleh $\mathrm{pH}$ yaitu $\mathrm{pH}$ yang lebih tinggi dan $\mathrm{pH}$ isoelektrik protein daging, sejumlah muatan positif dibebaskan dan terdapat surplus muatan negatif yang mengakibatkan penolakan dari 
myofilamen dan member lebih banyak ruang untuk molekul air. Bahan pengisi (filler) ternyata dapat meningkatkan daya mengikat air karena kemampuan menahan air selama proses pengolahan dan pemasakan. Pati mentah (tanpa perlakuan pemanasan) hanya akan menyerap air sampai kira-kira sepertiga beratnya, tetapi jika dipanaskan maka akan menyerap air beberapa kali lipat dan ukurannya akan bertambah beberapa kali lipat dari semula (Fardiaz dkk, 1992). Pada proses pemanasan sampai suhu $75^{\circ} \mathrm{C}$ adonan daging akan membentuk gel, setelah didinginkan akan membentuk padatan (Ockerman, 1983).

\section{Susut Masak.}

Susut masak diartikan sebagai persentase berat yang hilang dibandingkan dengan berat chicken nugget sebelum dimasak. Atau dapat dikatakan penurunan bobot yangbterjadi selama pemasakan. Soeparno (1994) menyatakan bahwa susut masak merupakan indicator terhadap nilai nutrisi daging dan berhubungan dengan banyaknya jumlah air terikat di didalam sel antara serabut otot.

Hasil pengamatan yang dilakukan terhadap besarnya persentase nilai rataan dari susut masak keempat macam chicken nugget mempunyai susut masak antara $1.50 \%$ 1,60\%. Hasil analisis keragaman menunjukkan perlakuan memberikan pengaruh yang tidak berbeda nyata terhadap susut masak semakin berkurang. Menurut Laakkonen (1973) kemampuan daging untuk mengikat air menurun dengan cepat bila suhu pemasakan meningkat, dengan demikian maka pada suhu yang lebih tinggi air di bebaskan lebih banyak dan susuk masak menjadi semakin besar. Pernyataan ini didukung pula oleh Arifin (1993) dalam penelitiannya yang menyatakan bahwa besarnya persentase cairan daging yang hilang selama pemasakan lebih banyak ditentukan oleh suhu dan lama pemasakan yang digunakan. Lawrie ( 1979) menyimpulkan bahwa pengaruh pemanasan terhadap struktur daging yang menghasilkan lunaknya jaringan ikat (konversi collagen menjadi gelatin) dan mengerasnya serta-serat daging karena koagulasi dari protein myofibril. Dalam penelitian ini semua perlakuan memperoleh suhu dan lama pemasakan yang sama yaitu $75^{\circ} \mathrm{C}$ selama 45 menit.

\section{Keempukan.}

Hasil pengukuran tingkat keempukan dari empat macam chicken nugget dalam penelitian ini dapat dilihat rata-rata tingkat keempukan dari empat macam chicken nugget bervariasi dari 0,97-1,02. Keempukkan chicken nugget selain dipengaruhi oleh penambahan filler juga dipengaruhi oleh daya mengikat air. 
Daya mengikat air yang tinggi mengakibatkan sedikit saja air yang hilang selama proses pemasakan chicken nugget, menyebabkan keempukan dan tekstur nugget lebih baik. Keempukan daging menurut para ahli banyak ditentukan setidak-tidaknya oleh tiga komponen daging yaitu struktur myofibril dan status kontraksinya, kandungan jaringan ikat dan tingkat ikatan silangnya, daya mengikat air oleh protein daging serta jus daging. Faktor yang mempengaruhi keempukan daging digolongkan menjadi faktor antemortem seperti genetic, bangsa, umur dan jenis kelamin, stress ternak dan factor postmortem seperti pelayuan, pembekuan, metode pengolahan termasuk pemasakan dan penambahan bahan pengempuk (Soeparno, 1994).

Berdasarkan hasil analisis keragaman menunjukkan perbedaan yang sangat nyata $(\mathrm{P}<0,01)$. Hal ini berarti bahwa penambahan bahan pengisi (filler) secara statistic memberikan perbedaan pada keempukan chicken nugget.Agar dapat mengetahui perlakuan mana yang berbeda secara statistik digunakan uji wilayah Duncan. Dari hasil uji ini ternyata perlakuan (T2) chicken nugget yang menggunakan tepung tapioka berbeda sangat nyata lebih tinggi $(\mathrm{P}>0,01)$ dibandingkan dengan $\mathrm{T} 1$ tapi tidak berbeda nyata $(\mathrm{p}>0,05)$ dengan T3 dan T4. Selanjutnya T3 berbeda sangat nyata dengan T1 tetapi tidak memberikan pengaruh yang berbeda sangat nyata dengan $\mathrm{T} 1$ tetapi tidak memberikan pengaruh yang berbeda dengan T4. Selanjutnya T4 sama dengan T4 sama dengan T1. Hal ini berarti perlakuan T1 (tepung sagu) menghasilkan nilai keempukan yang paling rendah (chicken nugget yang empuk). Sedangkan perlakuan T2 ( tepung tapioca) menghasilkan nilai keempukan yang paling rendah (chicken nugget yang empuk). Sedangkan perlakuan T2 (tepung tapioka) menghasilkan nilai keempukan yang tinggi, tetapi masih dalam kisaran nilai keempukan. Menurut Herscdoefer (1986) kisaran nilai keempukan mengikat air yang tinggi dari filler yang digunakan serta susut masak yang rendah mengakibatkan sedikit saja air yang hilang selama pembuatan chicken nugget menjadi lebih baik.

\section{KESIMPULAN}

Dari hasil penelitian ini disimpulkan bahwa bahan pengisi filler dengan menggunakan tepung tapioka (T2) dan tepung sagu (T1) menghasilkan chicken nugget yang lebih baik yang secara umum diterima oleh konsumen yang didukung oleh sifat fisik. 


\section{DAFTAR PUSTAKA}

Asyiek, j.1992. Daya Mengikat Air Ikan Kerupuk Kampelang menggunakan Ikan Hasil Pendinginan. Balai Penelitian dan Pengembangan Industri. Palembang.

Arifin, 1983. Pengaruh Lama dan Suhu Pemasakan Terhadap Kelarutan Protein dan Daya Mengikat Air Daging Sapi peranakan Ongole. Tesis. Program Pasca Sarjana IPB.Bogor.

Fardiaz,dkk.1992. Teknik Analisis Sifat Kimia dan Fungsional Komponen Pangan(Petunjuk Laboratorium) Depdikbud Dirjen Dikti. PAU Pangan dan Gizi.

Hamm,R. 1974.Water Holding Capasity of Meat. Proceeding of Twenty First Easter School In Agricultural Science.D.J.A.Cole and R.A Lawrie (Ed) University of Nottingham. Butterworths.

Herscdhoerfer.S.M. 1986.Quality Control in The Food Industry. Harcourt brace Jonovict,Publisher London Sandiago New York.

Indramorno,T.P. 1987. Pengaruh Lama Pelayuan dan Jenis Daging Karkas serta Jumlah Es yang Ditambahkan ke dalam Adonan Terhadap Sifat Fisik Kimia Bakso Daging Sapi.Tesis.Fateta.Bogor.

Laakonen,E. 1973. Factor Affecting Tenderness During Heating of Meat. Food research 20. Academic Press. New York .

Lawrie,R.A. 1997. Meat Science. Pergarmon Press.Oxford, New York.Toronto

Muctadi T.R. dan Sugiyono.1992.

Petunjuk Laboratorium Ilmu pengetahuan Bahan Pangan.Depdikbud.Direktorat jend.Pendidikan Tinggi Pusat antar Universitas Pangan dan Gizi Institut Pertanian Bogor.

Ockerman.W.H. 1983.Chemestry of Meat Tissue. Ohio.USA

Soeparno,1994. Ilmu dan Teknologi Daging.Edisi kedua.Gadjah Mada.University Press.Yogjakarta.

Swatland,H.J.1984. Structure and Development og Meat Animals. Prentiece-hall.Inc.Engelewood Cliffs.New Jersey.USA. 